\title{
HUBUNGAN PENGETAHUAN DAN DUKUNGAN KELUARGA DENGAN PEMERIKSAAN \\ DAHAK PADA PENDERITA SUSPEK TBC DI WILAYAH KERJA PUSKESMAS BRABASAN KABUPATEN MESUJI
}

\author{
Indra Wijaya ${ }^{1}$ \\ ${ }^{1}$ UPTD Puskesmas Brabasan Kabupaten Mesuji \\ Email: iw3276908@gmail.com
}

\section{ABSTRACT: THE CORRELATION OF KNOWLEDGE AND FAMILY SUPPORT WITH SPUTUM EXAMINATION IN PATIENTS WITH SUSPECTED TB IN THE WORK AREA OF BRABASAN HEALTH CENTER IN MESUJI}

Introduction: Achievement of positive smear pulmonary TB findings in Lampung Province, which is $38 \%$, has not reached the MSS target. Brabasan health center as many as 28 cases. As for the case of death at the Brabasan Community Health Center during 2017, there were 5 patients with pulmonary TB who died. the purpose knowing the relationship of knowledge and family support with sputum examination in patients with suspected TB in the work area of Brabasan Health Center in Mesuji Regency in 2020

Method: This type of research is quantitative, analytical survey research design with cross sectional approach. The population was all patients with suspected TB as many as 332 respondents, a sample of 182 respondents was taken by proportional random sampling. Univariate (frequency distribution) and bivariate data analysis used the chi square test.

Results:. It is known that of 182 respondents, most did not conduct an examination, namely $110(60.4 \%)$ respondents, 112 knowledge $(61.5 \%)$ respondents were poor, and negative family support was $94(51.6 \%)$ respondent. There is a knowledge relation (P-Value 0,000; OR 17,625). and family support (P-Value 0, 020; OR 2,142) with sputum examination in suspected TB patients in the Brabasan Community Health Center in Mesuji Regency in 2020

Conclusion: There is a relationship between knowledge and family support with sputum examination in suspected TB patients in the Brabasan Community Health Center in Mesuji Regency in 2020. Health promotion in the form of posters, banners, leaflets, baligo about the concept of compliance and other health concepts

Keywords: Knowledge, family support, sputum examination 


\section{INTISARI: HUBUNGAN PENGETAHUAN DAN DUKUNGAN KELUARGA DENGAN PEMERIKSAAN DAHAK PADA PENDERITA SUSPEK TBC DI WILAYAH KERJA PUSKESMAS BRABASAN KABUPATEN MESUJI TAHUN 2020}

Pendahuluan: Capaian angka penemuan penderita TB Paru BTA positif di Provinsi Lampung yaitu 38\% masih belum mencapai target SPM, Berdasarkan laporan tahunan Dinas Kesehatan Kabupaten Mesuji tahun 2017 angka penemuan pasien TB paru BTA (+) di Puskesmas Simpang pematang sebanyak 55 kasus, terendah di Puskesmas Brabasan sebanyak 28 kasus. Sedangkan untuk kasus kematian di Puskesmas brabasan selama tahun 2017 terdapat 5 orang pasien TB Paru yang meninggal. Tujuan penelitian diketahui hubungan pengetahuan dan dukungan keluarga dengan pemeriksaan dahak pada penderita suspek TBC di wilayah kerja Puskesmas Brabasan Kabupaten Mesuji tahun 2020.

Metode: Jenis penelitian kuantitatif, rancangan penelitian survey analitik pendekatan cross sectional. Populasi adalah seluruh pasien suspek TB sebanyak 332 responden, sampel sebanyak 182 responden diambil secara proportional random sampling. Analisa data secara univariat (distribusi frekuensi) dan bivariat menggunakan uji chi square.

Hasil:.Diketahui bahwa dari 182 responden, sebagian besar tidak melakukan pemeriksaan yaitu sebanyak $110(60,4 \%)$ responden, pengetahuan kurang baik sebanyak $112(61,5 \%)$ responden, dan dukungan keluarga negatif sebanyak 94 $(51,6 \%)$ responden. Ada hubungan pengetahuan $(P$-Value 0,000; OR 17,625). dan dukungan keluarga ( $P$-Value 0,020 ; OR 2,142) dengan pemeriksaan dahak pada penderita suspek TBC di wilayah kerja Puskesmas Brabasan Kabupaten Mesuji tahun 2020

Kesimpulan : Ada hubungan pengetahuan dan dukungan keluarga dengan pemeriksaan dahak pada penderita suspek TBC di wilayah kerja Puskesmas Brabasan Kabupaten Mesuji tahun 2020. Promosi kesehatan baik dalam bentuk poster, banner, leaflet, baligo tentang konsep kepatuhan maupun konsep kesehatan lainnya

Kata kunci : Pengetahuan, dukungan keluarga, pemeriksaan dahak

\section{PENDAHULUAN}

Tuberkulosis (TBC) masih merupakan masalah kesehatan global. Tuberkulosis adalah suatu penyakit menular yang disebabkan oleh kuman Mycobacterium tuberculosis. Indonesia merupakan salah satu negara yang mempunyai beban tuberkulosis yang terbesar diantara 8 negara yaitu India (27\%), China (9\%), Indonesia (8\%), Philippina (6\%), Pakistan (5\%), Nigeria (4\%), Bangladesh (4\%) dan Afrika Selatan (3\%) (WHO, 2019)

\begin{abstract}
Angka insiden tuberkulosis Indonesia pada tahun 2017 sebesar 319 per 100.000 penduduk dan angka kematian penderita tuberkulosis 40 per 100.000 penduduk Jumlah kasus tuberkulosis pada tahun 2018 ditemukan sebanyak 566.623 kasus, meningkat bila dibandingkan semua kasus tuberkulosis yang ditemukan pada tahun 2017 yang sebesar 446.732 kasus. Jumlah kasus tertinggi yang dilaporkan terdapat di provinsi dengan jumlah penduduk yang besar yaitu Jawa Barat sebesar 107.803 kasus sedangkan Provinsi Lampung
\end{abstract}


sebesar 15.969 kasus. Case Detection Rate (CDR) adalah jumlah semua kasus tuberkulosis yang diobati dan dilaporkan di antara perkiraan jumlah semua kasus tuberkulosis (insiden). Perkiraan jumlah semua kasus tuberkulosis merupakan insiden dalam per 100.000 penduduk dibagi dengan 100.000 dikali dengan jumlah penduduk. CDR menggambarkan seberapa banyak kasus tuberkulosis yang terjangkau oleh program, pada tahun 2018 CDR sebesar 67,2\%. Provinsi dengan CDR yang tertinggi adalah Provinsi DKI Jakarta (122,2\%), sedangkan CDR yang terendah adalah Provinsi Nusa Tenggara Barat $(29,0 \%)$ untuk Provinsi Lampung sebesar (45,1\%). Angka CDR Provinsi DKI Jakarta yang lebih dari 100\% (122,2\%) disebabkan karena terdapat penderita tuberkulosis yang terdeteksi di Fasilitas Pelayanan Kesehatan DKI Jakarta yang tidak hanya berasal dari wilayah DKI Jakarta namun dari wilayah luar Povinsi DKI Jakarta (Jabodetabek). (Kemenkes, 2019).

Berdasarkan Permenkes no 67 tahun 2016, terdapat berbagai strategi pemerintah dalam menurunkan kejadian TB paru, yaitu penguatan kepemimpinan program TB, peningkatan akses layanan TB yang bermutu, pengendalian faktor risiko $\mathrm{TB}$, peningkatan kemitraan $\mathrm{TB}$, peningkatan kemandirian masyarakat dalam Penanggulangan TB dan penguatan manajemen program TB (Permenkes no 67, 2016), namun strategi ini masih belum berhasil sesuai dengan harapan dikarenakan adanya beberapa wilayah khusunya di Provinsi Lampung yang belum mencapai target, dimana pada data diketahui jumlah BTA + sebanyak 5.612 penderita dengan Cure rate $75,69 \%$ dan sembuh sebesar $93 \%$. Angka Keberhasilan Pengobatan di Propinsi Lampung tahun 2016 sudah mencapai target yaitu 92,6 \%. Dengan cakupan tertinggi di Kabupaten Lampung Utara sebesar 100\% dan terendah di
Kabupaten Lampung Barat sebesar 24.36\% sedangkan Kabupaten Mesuji sebesar 82,23\% (Dinkes Propinsi Lampung, 2017).

Kabupaten Mesuji pada tahun 2016 terdapat suspek TB Paru 2,388 pasien, dengan angka kesembuhan (Cure Rate) 98\%, Pengobatan lengkap (Complete cate) $43,61 \%$, dan angka keberhasilan pengobatan (Sukses rate) $87,99 \%$. Tahun 2017, diketahui bahwa sebanyak 2.616 orang merupakan suspek TB dengan BTA+ sebanyak 327 orang menjalani pengobatan, sedangkan target pencapaian sebesar $90 \%$. Dengan angka kesembuhan (cure Rate ) 81,63\%, pengobatan lengkap (Complete rate) 38\% dan angka keberhasilan (Sukses Rate) (82,23\%). (Dinkes, 2017).

Angka penjaringan suspect adalah jumlah suspek yang diperiksa dahaknya diantara 100.000 penduduk pada suatu wilayah tertentu dalam satu tahun. Angka penjaringan suspek ini digunakan untuk mengetahui upaya penemuan pasien dalam suatu wilayah tertentu, dengan memperlihatkan kecenderungannya dari waktu ke waktu (Triwulan/tahunan) (Ditjen PP\&PL Kemenkes RI, 2011).

Rumus yang digunakan adalah jumlah suspek yang diperiksa dibagi jumlah penduduk dikali dengan $100 \%$. Penjaringan suspect Tb merupakan salah satu variabel penting evaluasi program penanggulangan penyakit TB. Angka Penjaringan Suspek sangat berperan dalam menentukan besarnya peluang untuk ditemukannya penderita TB, artinya semakin besar jumlah suspek yang didapat dan diperiksa maka peluang untuk 16 ditemukannya penderita TB diantara suspect juga semakin besar (Ariyanto \& Ramani, 2012).

Case Detection Rate (CDR) sebagai salah satu indikator pengendalian TB Paru, yaitu proporsi jumlah pasien baru BTA (+) yang ditemukan dan diobati 
terhadap jumlah pasien baru BTA (+) yang diperkirakan ada diwilayah tersebut. Pada tahun 2014, penemuan kasus TB Paru BTA positif (CDR) di Indonesia sebanyak 176.677 kasus. Menurun bila dibandingkan kasus baru BTA (+) yang ditemukan tahun 2013 yang sebesar 196.310 kasus. Jumlah kasus tertinggi yang dilaporkan terdapat di provinsi dengan jumlah penduduk yang besar yaitu Jawa Barat, Jawa Timur, dan Jawa Tengah. Kasus baru BTA+ di tiga provinsi tersebut sebesar $40 \%$ dari jumlah seluruh kasus baru di Indonesia (Kemenkes, 2015).

Provinsi Sumatera Barat target penemuan kasus BTA positif (CDR) yaitu 36,7\% (Dinkes Provinsi Lampung, 2015). Sedangkan pada tahun 2016 capaian angka penemuan penderita TB Paru BTA positif di Provinsi Lampung yaitu 38\% (Dinkes Provinsi Lampung, 2016). Pada tahun 2015 dan tahun 2016 masih belum mencapai target SPM, masih jauh dari target SPM yang harus dicapai

Berdasarkan laporan tahunan Dinas Kesehatan Kabupaten Mesuji tahun 2017 angka penemuan pasien TB paru BTA (+) dari beberapa Puskesmas yang ada terdapat di Mesuji kasus yang paling banyak ditemukan di Puskesmas Simpang pematang sebanyak 55 kasus, Puskesmas dengan penemuan kasus terendah yaitu Puskesmas Brabasan sebanyak 28 kasus. Sedangkan untuk kasus kematian di Puskesmas brabasan selama tahun 2017 terdapat 5 orang pasien TB Paru yang meninggal (Dinas Kesehatan Kabupaten Pesisir Selatan, 2017).

Kesehatan seseorang atau masyarakat dipengaruhi oleh dua faktor pokok, yakni faktor perilaku (behavior causes) dan faktor di luar perilaku (nonbehaviour causes). Selanjutnya perilaku itu sendiri ditentukan atau terbentuk dari 3 faktor : faktor predisposisi (predisposing factors), yang terwujud dalam pengetahuan, sikap, kepercayaan, keyakinan, nilai-nilai, dan sebagainya.Faktor pendukung (Enabling factors), yang terwujud dalam fasilitasfasilitas atau sarana-sarana, alat-alat kontrasepsi, jamban, dan sebagainya. Serta Faktor pendorong (renforcing factors) yang terwujud dalam sikap, dukungan keluarga dan perilaku petugas kesehatan atau petugas lain, yang merupakan kelompok referensi dari perilaku masyarakat.

Penelitian Arivany (2017) Hasil penelitian menunjukkan bahwa contingency coefficient pengetahuan responden suspek TB paru dalam melakukan pemeriksaan sputum adalah 0,253 dan $O R=3,600$. Kesimpulan terdapat hubungan yang lemah antara pengetahuan responden dengan tindakan dalam melakukan pemeriksaan sputum. Gejala dan penanganan TB paru dapat diketahui jika petugas kesehatan bekerja sama dengan tokoh agama dan tokoh masyarakat untuk memberikan informasi sesuai usia dan pendidikan dari responden.

Menurut Wahyudi

(2018) keberhasilan penemuan suspek TB Paru sangat dipengaruhi oleh pengetahuan tentang cara penemuan itu sendiri, tanpa ada upaya pembekalan kepada petuga secara komprehensif kepada para petugas cenderung menyebakan cakupan penemuan yang semakin rendah, Pengetahuan tentang mekanisme penemuan dan penanganan suspek TB Paru sangat penting bagi kader, karena tanpa memahami bagaimana mekanisme yang harus dijalani untuk menemukan suspek TB Paru dan cara penanganan.

Selain pengetahuan dukungan keluarga juga menjadi salah satu penyebab, Dukungan keluarga berpengaruh pada kepatuhan minum obat pada pasien tuberkulosis dalam fase intensif. Kecenderungan penderita untuk bosan dan putus berobat saat pengobatan karena sudah memakan 
waktu yang lama merupakan salah satu faktor ketidakpatuhan itu sendiri. Individu yang termasuk dalam memberikan dukungan sosial meliputi pasangan (suami/istri), orang tua, anak dan sanak keluarga. Secara fungsional dukungan sosial mencakup dukungan emosional dengan mendorong adanya ungkapan perasaan, memberi nasihat atau informasi dan pemberi bantuan material (Rumimpunu, 2018)

Berdasarkan hasil prasurvey yang dilakukan peneliti tanggal 19-23 November 2019 di UPTD Puskesmas Brabasan, berdasarkan data rekam medik diketahui bahwa kejadian TB paru tahun 2016 sebanyak 22 orang, di tahun 2017 meningkat menjadi 28 orang dan di tahun 2018 kembali mengalami peningkatan menjadi 46 orang, sepanjang tahun 2019 penderita TB bertambah sebanyak 12 orang, sehingga total penderita TB paru sebanyak 46 orang. Sedangkan pasien suspek TB di bulan Juli - Desember tahun 2019 diketahui sebanyak 332 orang, dimana dari jumlah tersebut sebanyak 116 orang atau sebesar $34,9 \%$ sudah melakukan pemeriksaan dahak dan sebanyak $65,0 \%$ belum melakukan pemeriksaan dahak.

Berdasarkan hasil prasurvey yang dilakukan terhadap 10 orang suspek penderita TB diketahui bahwa $70 \%$ pasien tidak mengetahui bahwa penyakit yang dideritanya mengarah ke penyakit TB, responden hanya merasa bahwa batuk biasa yang tidak kunjung sembuh dan responden merasa mengalami penurunan berat badan selain itu sebanyak $60 \%$ responden mengungkapkan bahwa keluarga belum sempat untuk mengantarkan responden dalam pemeriksaan dahak

Berdasarkan masalah tersebut di atas maka peneliti tertarik untuk meneliti lebih jauh mengenai hubungan pengetahuan dan dukungan keluarga dengan pemeriksaan dahak pada penderita suspek TBC di wilayah kerja Puskesmas Brabasan Kabupaten Mesuji tahun 2020.

\section{METODE PENELITIAN}

Penelitian ini merupakan penelitian kuantitatif, dengan jenis penelitian crossectional. Populasi dalam penelitian ini adalah seluruh penderita suspect TB paru pengambilan sampel secara purposive sampling yaitu berdasarkan kriteria yang diinginkan oleh peneliti direncanakan di wilayah kerja Puskesmas Brabasan Kabupaten Mesuji tahun 2020, Penelitian telah dilakukan 22-30 Juli 2020. Variabel yang diambil adalah pengetahuan, dukungan keluarga dan pemeriksaan dahak pada penderita suspek TBC, pengambilan data menggunakan kuesioner yang dibagikan ke responden.Analisis data secara univariat dan bivariat (chi square). 


\section{HASIL PENELITIAN DAN PEMBAHASAN}

Analisis Univariat

Distribusi frekuensi pemeriksaan dahak pada penderita suspek TBC, pengetahuan dan dukungan keluarga di wilayah kerja Puskesmas Brabasan Kabupaten Mesuji

\begin{tabular}{llll}
\hline Variabel & Kategori & Frekuensi & Persentase (\%) \\
\hline Melakukan & Ya & 72 & 39,6 \\
Pemeriksaan Dahak & Tidak & 110 & 60,4 \\
pengetahuan & Baik & 70 & 38,5 \\
& kurang baik & 112 & 61,5 \\
dukungan keluarga & Positif & 88 & 48,4 \\
& Negatif & 94 & 51,6 \\
\hline Total & & 182 & 100,0 \\
\hline
\end{tabular}

Berdasarkan tabel diatas pengetahuan kurang baik sebanyak diketahui bahwa dari 182 responden, $\quad 112(61,5 \%)$ responden dan sebagian sebagian besar tidak melakukan besar dukungan keluarga negatif pemeriksaan yaitu sebanyak 110 sebanyak $94(51,6 \%)$ responden. $(60,4 \%)$ responden, responden dengan

Analisis Bivariat

Hubungan pengetahuan dengan pemeriksaan dahak pada penderita suspek TBC di wilayah kerja Puskesmas Brabasan Kabupaten Mesuji

\begin{tabular}{|c|c|c|c|c|c|c|c|c|}
\hline \multirow{3}{*}{ pengetahuan } & \multicolumn{4}{|c|}{ Pemeriksaan dahak } & \multirow{3}{*}{$\mathbf{N}$} & \multirow{3}{*}{$\%$} & \multirow{3}{*}{$p$-value } & \multirow{3}{*}{$\begin{array}{c}\text { OR } \\
\text { CI } 95 \%\end{array}$} \\
\hline & \multicolumn{2}{|c|}{ Melakukan } & \multicolumn{2}{|c|}{$\begin{array}{c}\text { Tidak } \\
\text { melakukan }\end{array}$} & & & & \\
\hline & $\mathrm{n}$ & $\%$ & $\mathrm{n}$ & $\%$ & & & & \\
\hline Baik & 54 & 77,1 & 16 & 22,9 & 70 & 100,0 & & 17,625 \\
\hline Kurang baik & 18 & 16,1 & 94 & 83,9 & 112 & 100,0 & 0,000 & $\begin{array}{l}(8,309- \\
37,387)\end{array}$ \\
\hline Total & 72 & 39,6 & $\begin{array}{c}11 \\
0\end{array}$ & 60,4 & 182 & 100,0 & & \\
\hline
\end{tabular}

Berdasarkan Tabel di atas dapat diketahui dari 70 responden dengan pengetahuan baik, sebanyak 54 $(77,1 \%)$ responden melakukan pemeriksaan dahak, dari 112 responden dengan pengetahuan kurang baik sebanyak $18 \quad(16,1 \%)$ responden melakukan pemeriksaan dahak dan sebanyak $94 \quad(83,9 \%)$ responden tidak melakukan pemeriksaan dahak.

Hasil uji statistik diperoleh $p$ value $=0,000$ yang berarti $\mathrm{p}$-value $<\mathrm{a}$
$(0,05)$, maka dapat disimpulkan bahwa hubungan pengetahuan dengan pemeriksaan dahak pada penderita suspek TBC di wilayah kerja Puskesmas Brabasan Kabupaten Mesuji. Hasil statistik diperoleh 17,625 artinya responden dengan pengetahuan baik memiliki peluang untuk melakukan pemeriksaan dahak sebesar 17,625 kali jika dibandingkan dengan responden dengan pengetahuan kurang baik. 
Hubungan dukungan keluarga dengan pemeriksaan dahak pada penderita suspek TBC di wilayah kerja Puskesmas Brabasan Kabupaten Mesuji tahun 2020

\begin{tabular}{lcccccccc}
\hline \multirow{2}{*}{$\begin{array}{l}\text { Dukungan } \\
\text { keluarga }\end{array}$} & \multicolumn{2}{c}{ Pemeriksaan Dahak } & \multicolumn{2}{c}{ Tidak } & $\mathrm{N}$ & $\%$ & $p$-value & Cl 95\% \\
& $\mathrm{n}$ & $\%$ & $\mathrm{n}$ & $\%$ & & & & \\
\hline Positif & 43 & 48,9 & 45 & 51,1 & 88 & 100 & & 2,142 \\
Negatif & 29 & 30,9 & 65 & 69,1 & 94 & 100 & 0,020 & $(1,169-$ \\
Total & 72 & 39,6 & 11 & 60,4 & 182 & 100,0 & & \\
\hline
\end{tabular}

Berdasarkan Tabel 4.3 dapat diketahui dari 88 responden dengan dukungan keluarga positif, sebanyak $43(48,9 \%)$ responden melakukan pemeriksaan dahak dan sebanyak 45 $(51,1 \%)$ responden tidak melakukan pemeriksaan dahak. Dari 94 responden dengan dukungan keluarga negatif sebanyak $29 \quad(30,9 \%)$ responden melakukan pemeriksaan dahak dan sebanyak $65(69,1 \%)$ responden tidak melakukan pemeriksaan dahak.

Hasil uji statistik diperoleh $p$ value $=0,020$ yang berarti $p$-value $<a$

\section{PEMBAHASAN}

Hubungan pengetahuan dengan pemeriksaan dahak pada penderita suspek TBC di wilayah kerja Puskesmas Brabasan Kabupaten Mesuji tahun 2020

Hasil uji statistik diperoleh $p$-value = 0,000 yang berarti $p$-value< $\alpha(0,05)$, maka dapat disimpulkan bahwa hubungan pengetahuan dengan pemeriksaan dahak pada penderita suspek TBC di wilayah kerja Puskesmas Brabasan Kabupaten Mesuji tahun 2020. Hasil statistik diperoleh 17,625 artinya responden dengan pengetahuan baik memiliki peluang untuk melakukan pemeriksaan dahak sebesar 17,625 kali jika dibandingkan dengan responden dengan pengetahuan kurang baik
$(0,05)$, maka dapat disimpulkan bahwa ada hubungan dukungan keluarga dengan pemeriksaan dahak pada penderita suspek TBC di wilayah kerja Puskesmas Brabasan Kabupaten Mesuji tahun 2020, hasil statistik diperoleh 2,142 artinya responden dengan dukungan keluarga positif memiliki peluang untuk melakukan pemeriksaan dahak sebesar 2,142 kali jika dibandingkan dengan responden dengan dukungan keluarga negatif.

Pengetahuan adalah hasil dari tahu dan ini setelah orang melakukan penginderaan dengan pelaksanaan obyek tertentu. Penginderaan terjadi melalui panca indera manusia, yakni indera penglihatan, pendengaran, penciuman, rasa dan raba. Sebagaian besar pengetahuan manusia diperoleh melalui mata dan telingaDapat disimpulkan bahwa pengetahuan merupakan segala sesuatu yang diketahui yang diperoleh dari persentuhan panca indera dengan pelaksanaan objek tertentu. Pengetahuan pada dasarnya merupakan hasil dari proses melihat, mendengar, merasakan, dan berfikir yang menjadi dasar manusia dan bersikap dan bertindak. Dalam pengamatan seharihari diperoleh kejelasan, jika suatu 
perbuatan yang didasarkan oleh pengetahuan akan langgeng dari pada perbuatan yang tidak didasari oleh pengetahuan(Budiman, 2013). Sebagian besar pengetahuan manusia diperoleh melalui mata dan telinga, sehingga penggunaan panca indera terhadap suatu informasi sangat penting (Nugroho dalam Hendrawati 2018). yang mempengaruhi kepatuhan salah satunya adalah factor pengetahuan. Pengetahuan adalah merupakan hasil mengingat suatu hal, termasuk mengingat kembali kejadian yang pernah dialami baik secara sengaja maupun tidak sengaja dan ini terjadi setelah orang malakukan kontak atau pengamatan terhadap suatu obyek tertentu (Mubarok, dkk, dalam Hendrawati 2018).

Menurut penelitian Arivany (2017) Contingency Coefficient pengetahuan responden suspek TB paru dalam melakukan pemeriksaan sputum adalah 0,253 dan $\mathrm{OR}=3,600$. Kesimpulan terdapat hubungan yang lemah antara pengetahuan responden dengan tindakan dalam melakukan pemeriksaan sputum.

Berdasarkan hasil penelitian diketahui bahwa dari 70 responden dengan pengetahuan baik, sebanyak 54 $(77,1 \%)$ responden melakukan pemeriksaan dahak hal ini sejalan dengan teori yang mengungkapkan bahwa semakin baik pengetahuan seseorang maka semakin baik perilaku yang di tunjukkan dalam hal ini adalah melakukan pemeriksaan dahak dan sebanyak $16(22,9 \%)$ tidak melakukan pemeriksaan dahak hal ini dimungkinkan adanya faktor lain seperti kurangnya dukungan keluarga dimana responden ingin melakukan pemeriksaan namun terkendala tidak ada yang mengantar atau kurangnya biaya untuk ke fasilitas kesehatan atau faktor lain yang tidak diambil dalam penelitian ini sehingga responden tidak melakukan pemeriksaan dahak, berdasarkan hasil penelitian dketahui dari 112 responden dengan pengetahuan kurang baik sebanyak 18 $(16,1 \%)$ responden melakukan pemeriksaan dahak hal ini dimungkinkan adanya faktor lain seperti adanya peran petugas kesehatan untuk memotivasi responden sehingga mau melakukan pemeriksaan dahak atau adanya dukungan keluarga yang memotivasi responden sehingga melakukan pemeriksaan dahak dan sebanyak 94 $(83,9 \%)$ responden tidak melakukan pemeriksaan dahak hal ini dikarenakan responden tidak mengetahui manfaat dari pemeriksaan dahak bagi dirinya yang merupakan penderita suspec TB sehingga dibutuhkan peran petugas kesehatan untuk lebih berperan aktif sehingga pengetahuan meningkat dan responden mau melakukan pemeriksaan dahak.

Menurut peneliti Pengetahuan yang baik kemungkinan dipengaruhi oleh banyak factor, misalnya pengalaman, sarana informasi. Pengetahuan tidak hanya didapat secara formal melainkan melalui pengalaman. Selain itu pengetahuan dipengaruhi oleh sarana informasi yang terseian di rumah seperti televise dan radio. Pemeriksaan dahak berfungsi untuk menegakkan diagnosis, menilai keberhasilan pengobatan dan menentukan potensi penularan. Pemeriksaan dahak untuk penegakan diagnosis dilakukan dengan mengumpulkan 3 spesimen dahak yang dikumpulkan dalam dua hari kunjungan yang berurutan berupa Sewaktu-PagiSewaktu (SPS)

Hubungan dukungan keluarga dengan pemeriksaan dahak pada penderita suspek TBC di wilayah kerja Puskesmas Brabasan Kabupaten Mesuji tahun 2020 Hasil uji statistik diperoleh $p$-value $=$ 0,020 yang berarti $p$-value $<a \quad(0,05)$, maka dapat disimpulkan bahwa ada hubungan dukungan keluarga dengan 
pemeriksaan dahak pada penderita suspek TBC di wilayah kerja Puskesmas Brabasan Kabupaten Mesuji tahun 2020, hasil statistik diperoleh 2,142 artinya responden dengan dukungan keluarga positif memiliki peluang untuk melakukan pemeriksaan dahak sebesar 2,142 kali jika dibandingkan dengan responden dengan dukungan keluarga negatif.

Dukungan keluarga adalah tingkah laku spesifik yang diharapkan oleh seseorang dalam konteks keluarga (Padila, 2012).Peran berdasarkan pada pengharapan atau penetapan peran yang membatasi apa saja yang dilakukan oleh individu di dalam situasi tertentu agar memenuhi pengharapan diri atau orang lain terhadap mereka. Dukungan sosial keluarga adalah sebuah proses yang terjadi sepanjang masa kehidupan, sifat dan jenis dukungan sosial berbedabeda dalam berbagai tahap-tahap siklus kehidupan. Namun demikian, dalam semua tahap siklus kehidupan, dukungan sosial keluarga membuat keluarga mampu berfungsi dengan berbagai kepandaian dan akal.Sebagai akibatnya, hal ini meningkatkan kesehatan dan adaptasi keluarga (Friedman, 2014).

Hubungan keluarga yang harmonis akan memberikan ketenangan dan mengurangi bebanyang dirasakan karena pada saat seseorang menghadapi tekanan dan kesulitan hidup seseorang memerlukan orang lain untuk berbagi, mendengarkan atau mencari informasi yang relevan. Sehingga dukungan keluarga dalam bentuk dukungan informasi, dukungan emosional, dukungan penghargaan dan dukungan instrumental akan membuat pasien hipertensi memiliki kepatuhan yang baik dalam pengendalian hipertensi Friedman (2014). Hal ini sesuai dengan teori Feurerstein et al (1986) dalam Niven (2013) yang menyatakan keluarga dapat menjadi faktor yang mempengaruhi dalam menentukan keyakinan dan nilai kesehatan individu serta dapat menentukan tentang program pengobatan yang diterima (Imran, 2017). Menurut Kuntjoro (dalam Imran, 2017) menyatakan bahwa salah satu faktor yang mempengaruhi perilaku anggota keluarga adalah sejauh mana keluarga memberikan dukungan kepada anggota keluarganya.

Menurut penelitian Subhakti (2018) yang berjudul Hubungan Dukungan Keluarga Dengan Tindakan Penderita Tb Paru Melakukan Kontrol Ulang Di Puskesmas Sidomulyo Berdasarkan dukungan keluarga, responden yang mempunyai dukungan keluarga yang positif yaitu sebanyak 23 responden $(56,1 \%)$ dan 31 responden $(75,6 \%)$ di antaranya memiliki tindakan untuk melakukan kontrol ulang secara rutin di Puskesmas. Hasil uji disimpulkan bahwa ada hubungan yang signifikan antara dukungan keluarga dengan tindakan penderita TB Paru melakukan kontrol ulang di Puskesmas Sidomulyo.

Berdasarkan hasil penelitian dari 88 responden dengan dukungan keluarga positif, sebanyak $43(48,9 \%)$ responden melakukan pemeriksaan dahak hal ini sejalan dengan teori yang menyatakan bahwa dukungan keluarga yang baik akan memotivasi responden dalam berperilaku yang baik dalam hal ini adalah melakukan pemeriksaan dahak dan sebanyak $45(51,1 \%)$ responden tidak melakukan pemeriksaan dahak menurut peneliti adanya faktor lain seperti pengetahuan responden yang kurang baik sehingga responden kemungkinana merasa tidak perlu untuk melakukan pemeriksaan dahak.. Dari 94 responden dengan dukungan keluarga negatif sebanyak 29 (30,9\%) responden melakukan pemeriksaan dahak hal ini dimungkinkan pengetahuan responden yang baik sehingga walaupun keluarga kurang mendukung namun responden 
tetap melakukan pemeriksaan dahak atau adanya faktor lain seperti adanya dukungan petugas kesehatan dan sebanyak $65(69,1 \%)$ responden tidak melakukan pemeriksaan dahak hal ini sejalan dengan teori yang mengungkapkan bahwa dukungan responden mempengaruhi perilaku seseorang. Menurut pendapat peneliti Dukungan yang diberikan oleh keluarga akan membuat pasien merasa berharga karena masih ada orang yang mencintai dan memperhatikan. Hubungan keluarga yang harmonis akan memberikan ketenangan dan mengurangi bebanyang dirasakan karena pada saat seseorang menghadapi tekanan dan kesulitan hidup seseorang memerlukan orang lain untuk berbagi, mendengarkan atau mencari informasi yang relevan

\section{KESIMPULAN}

1. Diketahui bahwa dari 182 responden, sebagian besar tidak melakukan pemeriksaan yaitu sebanyak 110 $(60,4 \%)$ responden, responden dengan pengetahuan kurang baik sebanyak $112(61,5 \%)$ responden, dan dukungan keluarga negatif sebanyak 94 (51,6\%) responden

2. Ada hubungan pengetahuan dengan pemeriksaan dahak pada penderita suspek TBC di wilayah kerja Puskesmas Brabasan Kabupaten Mesuji tahun 2020. Hasil statistik diperoleh 17,625 (P-Value 0,000; OR 17,625).

3. Ada hubungan dukungan keluarga dengan pemeriksaan dahak pada penderita suspek TBC di wilayah kerja Puskesmas Brabasan Kabupaten Mesuji tahun 2020 (P-Value 0, 020; OR 2,142).

\section{Saran}

\section{Bagi Puskesmas}

a. Memberikan pendidikan kesehatan kepada penderita TBC Paru tentang manfaat pemeriksaan dahak sesuai dengan saran dan pengobatan secara maksimal sehingga dapat menurunkan kejadian TBC Paru

b. Promosi kesehatan baik dalam bentuk poster, banner, leaflet, baligo tentang konsep kepatuhan maupun konsep kesehatan lainnya

c. Mengoptimalkan kegiatan-kegiatan yang mengikutsertakan keluarga pasien yang lebih menonjolkan kemampuan positif seperti mempraktikan atau menanyakan seputar penyakit TBC, sehingga mereka memahami tentang pentingnya pemeriksaan dahak bagi penderita TBC dan patuh konsumsi minum obat TBC Paru pada penderita TBC Paru.

d. Membuat suatu wadah komunitas sehingga mempermudah pemberian informasi dan sebagai sarana untuk saling berkomunikasi antara penderita TBC Paru

2. Bagi penderita TBC Paru dan keluarga

a. Meningkatkan pengetahuan dengan cara, mencari informasi kepada petugas kesehatan sehingga dapat mengubah sikap menjadi lebih baik.

b. Selalu menghadiri penyuluhan yang diberikan oleh petugas kesehatan terkait dengan penyakit yang diderita

c. Ikut serta dalam penyuluhan yang diberikan oleh petugas kesehatan terkait dengan penyakit TBC Paru pada penderita TBC Paru .

d. Meningkatkan dukungan kepada penderita TBC Paru dengan cara mengingatkan untuk kontrol rutin dan melakukan pemeriksaan dahak sesuai dengan jadwal serta rutin untuk konsumsi minum obat.

e. Selalu memberikan dukungan dalam bentuk informasi, emosial, finansial sehingga penderita TBC Paru tidak merasa sendiri terhadap masalah yang dihadapi. 
3. Bagi Universitas Malahayati

Bagi universitas malahayati dapat melakukan kerjasma lintas sektoral pada dinas keshatan atau puskesmas setempat untuk berkerja sama dalam memberikan KIE pada masyarakat mengenai pentingnya pemeriksaan dahak jika memiliki tanda dan gejala TB.

4. Bagi Peneliti Selanjutnya

Bagi peneliti selanjutnya yang berminat untuk melanjutkan penelitian ini, diharapkan untuk meneliti dengan metode yang berbeda seperti menggali hal-hal apa saja yang lebih berpotensi menyebabkan terjadinya kepatuhan pemeriksaan dahak bagi penderita TBC Paru selain pendidikan, pekerjaan, sikap maupun status ekonomi, melakukan intervensi, konseling yang dapat mempengaruhi sikap penderita TBC Paru untuk melakukan pemeriksaan dahak.

\section{DAFTAR PUSTAKA}

Arikunto, S. (2013). Prosedur Penelitian:

Suatu Pendekatan Praktik. Jakarta: Rineka Cipta.

Afriyani, P. F. (2016). Hubungan Pengetahuan Dan Sikap Pada Responden Suspek TB Paru Dengan Tindakan Dalam Melakukan Pemeriksaan Sputum (Dahak) Di Puskesmas Kamoning Kabupaten Sampang (Doctoral Dissertation, Universitas Airlangga).

Arivany, P. F. (2017). The Knowledge of Lung Tuberculosis Suspects for Sputum Examination Attitude In The Kamoning Primary Health Care. Jurnal Berkala Epidemiologi, 5(1), 75 84.

Bratanegara, A. S. (2012). Gambaran Dukungan Keluarga Terhadap Pemanfaatan Posbindu Lansia Di Kelurahan Karasak Kota Bandung. Students e-Journal, 1(1), 28.
Budiman, R. A. (2013). Kapita selekta kuesioner pengetahuan dan sikap dalam penelitian kesehatan. Jakarta: Salemba Medika, 1-18.

Daulay. (2016). Hubungan Pengetahuan Penderita TB Paru, Penyuluhan Kesehatan dan Pengawas Menelan Obat dengan Tingkat Kepatuhan Berobat di Puskesmas Langkimat Kecamatan Simangambat Kabupaten Padang Lawas Utara Tahun 2015. Universitas Sumatera Utara.

Depkes, R. I. (2007). Pedoman Nasional Penanggulangan Tuberkulosis, edisi 2. Jakarta: Gerdunas-TB (Gerakan Terpadu Nasional Penanggulangan Tuberkulosis).

Dharma, Kusuma Kelana (2011), Metodologi Penelitian Keperawatan : Panduan. Jakarta: Trans InfoMedia.

Dinas kesehatan lampung.(2015). Profil kesehatan provinsi lampung tahun 2014. Lampung.

Dinas kesehatan lampung.(2017). Profil kesehatan provinsi lampung tahun 2016. Lampung.

Friedman, M. (2014). Buku Ajar Keperawatan keluarga : Riset, Teori, dan Praktek. Edisi ke-5. Jakarta: EGC.

Kemenkes, R. I. (2011). Pedoman Nasional Penanggulangan Tuberkulosis. Jakarta: Direktorat Jendral Pengendalian Penyakit dan Penyakit Lingkungan Kemenkes RI.

Kementerian Kesehatan Republik Indonesia. (2019). Profil kesehatan indonesia tahun 2018. Jakarta.

Mubarak, W.I. (2012). Promosi kesehatan untuk kebidanan. Jakarta: salemba.

Notoatmodjosoekidjo.

(2012). Metodologi penelitian kesehatan. Jakarta: rineka cipta.

Notoatmodjo, S. (2014).Promosi Kesehatan dan Ilmu Perilaku.Jakarta : Rineka. Cipta

Nursalam, (2016). Manajemen Keperawatan, Aplikasi dalam Prakik 
Keperawatan Profesional. Jakarta Salemba Medika.

Padila.(2012). Buku Ajar Keperawatan Keluarga. Yogyakarta: Nuha Medika

Permenkes, R. I. No. 67 tahun 2016.Penanggulangan Tuberculosis.

Price, a. Sylvia, lorraine mc. Carty wilson.(2012).Patofisiologi : konsep klinis. Proses-proses penyakit, edisi 6, (terjemahan), peter anugrah. Jakatra: egc.

Priyoto. (2014). Teori Perubahan Perilaku Dalam Kesehatan. Yogyakarta: NuhaMedika

Riyanto, A (2017), Aplikasi Metodologi Penelitian Kesehatan. Jakarta : Nuha Medika,

Smeltzer dan bare. (2009). Buku ajar keperawatan medikal bedah brunner suddarth.

Kesehatan

dan kebahagiaan. Jakarta: pt. Gramedia utama.
Subhakti, K. A. (2014). Hubungan dukungan keluarga dengan tindakan penderita TB paru melakukan kontrol ulang di Puskesmas Sidomulyo (Doctoral dissertation, Riau University).

Sugiyono. (2017). Metode penelitian kualitatif, kuantitatif r\&d. Bandung: alfabeta.

Widari. (2016). Faktor-Faktor yang Memengaruhi Kepatuhan Pengobatan Penderita TB Paru di Puskesmas Kecamatan Beringin Kabupaten Deli Serdang. Universitas Sumatera Utara. Widoyono. (2011). Penyakit tropis. Jakarta : erlangga medical series.

World Health Organisation. (2018).Global tuberculosis report 2018. France: World Health Organization. 